\title{
"The relationship between compensation committee quality and the voluntary adoption of clawback provisions"
}

\begin{tabular}{|c|c|}
\hline \multirow{4}{*}{ AUTHORS } & Hui-Wen Hsu (D https://orcid.org/0000-0002-4786-1532 \\
\hline & Liu-Ching Tsai (D https://orcid.org/0000-0002-5017-3802 \\
\hline & Chaur-Shiuh Young (D) https://orcid.org/0000-0003-3874-7663 \\
\hline & Chia-Hui Chen (D https://orcid.org/0000-0001-8440-3410 \\
\hline ARTICLE INFO & $\begin{array}{l}\text { Hui-Wen Hsu, Liu-Ching Tsai, Chaur-Shiuh Young and Chia-Hui Chen (2018). } \\
\text { The relationship between compensation committee quality and the voluntary } \\
\text { adoption of clawback provisions. Investment Management and Financial } \\
\text { Innovations, 15(4), 345-355. doi:10.21511/imfi.15(4).2018.28 }\end{array}$ \\
\hline DOI & http://dx.doi.org/10.21511/imfi.15(4).2018.28 \\
\hline RELEASED ON & Friday, 21 December 2018 \\
\hline RECEIVED ON & Wednesday, 11 April 2018 \\
\hline \multirow{2}{*}{ ACCEPTED ON } & Wednesday, 19 December 2018 \\
\hline & $(\mathrm{cc})$ EY \\
\hline LICENSE & $\begin{array}{l}\text { This work is licensed under a Creative Commons Attribution } 4.0 \text { International } \\
\text { License }\end{array}$ \\
\hline JOURNAL & "Investment Management and Financial Innovations" \\
\hline ISSN PRINT & $1810-4967$ \\
\hline ISSN ONLINE & $1812-9358$ \\
\hline PUBLISHER & LLC "Consulting Publishing Company "Business Perspectives" \\
\hline FOUNDER & LLC "Consulting Publishing Company "Business Perspectives" \\
\hline
\end{tabular}

NUMBER OF REFERENCES

47
NUMBER OF FIGURES

0

\section{ニニะ}

NUMBER OF TABLES

3

(C) The author(s) 2022. This publication is an open access article. 


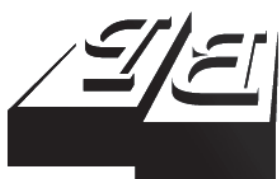

BUSINESS PERSPECTIVES

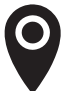

LLC "CPC "Business Perspectives" Hryhorii Skovoroda lane, 10, Sumy, 40022, Ukraine

www.businessperspectives.org

Received on: $11^{\text {th }}$ of April, 2018 Accepted on: $19^{\text {th }}$ of December, 2018

(C) Hui-Wen Hsu, Liu-Ching Tsai, Chaur-Shiuh Young, Chia-Hui Chen, 2018

Hui-Wen Hsu, Associate Professor, Department of Public Finance, Feng Chia University, Taiwan.

Liu-Ching Tsai, Professor,

Department of Banking and Finance, National Chia-Yi University, Taiwan.

Chaur-Shiuh Young, Professor, Department of Accountancy and Graduate Institute of Finance and Banking, National Cheng Kung University, Taiwan.

Chia-Hui Chen, Assistant Professor, Department of Accounting, National Dong Hwa University, Taiwan.

\section{(ㄷ) (i)}

This is an Open Access article, distributed under the terms of the Creative Commons Attribution 4.0 International license, which permits unrestricted re-use, distribution, and reproduction in any medium provided the original work is properly cited.
Hui-Wen Hsu (Taiwan), Liu-Ching Tsai (Taiwan), Chaur-Shiuh Young (Taiwan), Chia-Hui Chen (Taiwan)

\section{THE RELATIONSHIP BETWEEN COMPENSATION COMMITTEE QUALITY AND THE VOLUNTARY ADOPTION OF CLAWBACK PROVISIONS}

\begin{abstract}
This paper examines how compensation committee quality is related to the voluntary adoption of clawback provisions. Because fair value information has some reliability issues, this paper further examines whether the amount of Level 3 fair values affect the relationship between compensation committee quality and the voluntary adoption of clawback provisions. Using a sample drawn from the U.S. firms from 2008 to 2015 , the results show that the compensation committee quality is positively related to the voluntary adoption of clawback provisions. Additionally, the positive relationship between compensation committee quality and the voluntary adoption of clawback provisions is more pronounced for firms with higher Level 3 fair values.
\end{abstract}

\section{Keywords compensation committee quality, clawback provisions, Level 3 fair values}

\section{JEL Classification G34, J33, M41}

\section{INTRODUCTION}

In recent years, clawback provisions have been increasingly prevalent as a punishment mechanism that links the CEO compensation to their financial reporting behavior (Chan et al., 2012; Chan et al., 2015; Dehaan et al., 2013; Iskandar-Datta \& Jia, 2013). Clawback provisions allow firms to recoup CEO compensation to the extent it is determined that corporate performance goals were not achieved, thereby reducing the incentives of managers to manipulate earnings. Thus, clawback provisions create tension between executives and boards (Scott \& Seelig, 2010).

The prior research provides evidence about the consequences of clawback provisions and indicates that managers, analysts (Dehaan et al., 2013), investors (Iskandar-Datta \& Jia, 2013), and auditors (Chan et al., 2012) may react to the adoption of clawbacks. Recent research also examines the economic determinants of firms' voluntary adoptions (Addy et al., 2014; Brown et al., 2015; Huang et al., 2015). However, the viewpoint of corporate governance has been less directly examined, with the exception of few studies. Using an index of corporate governance, Addy et al. (2014) find that firms with entrenchment management make clawback provisions less likely, and the compensation committee's social ties with other adopters increase the implementation of clawback provisions. Huang et al. (2015) indicate that firms with more co-opted boards are less likely to have clawback provisions and the relationship is more pronounced when there are co-opted directors 
on the compensation committee. Chen and Vann (2017) indicate that firms with strong governance are positively related to the adoption of clawback provisions. Compared to the prior literature, which does not consider the role of compensation committee, this paper uses seven measures for compensation committee quality, because the measure of compensation committee quality is more comprehensive.

All the corporate activity is the responsibility of the board of directors; however, compensation-related matters are assigned to compensation committees (Conyon \& Peck, 1998; Collins et al., 2009). Because clawbacks concern the CEO's compensation, this task would be delegated to the compensation committee (Huang et al., 2015). Since boards have fiduciary duties to shareholders, the compensation committee may adopt a clawback provision. Adoption of clawback provisions reflects independence and vigilance and illustrates that board interests coincide with those of outsiders. Thus, this paper constructs one index that describes compensation committee quality to examine whether companies with higher compensation committee quality are more likely to adopt clawback provisions. The attributes of compensation committee quality that this study investigates include the degrees of independence and professionalism of the directors. The level of professionalism of committees affects their ability to monitor management and is of particular importance given the current issue. The second purpose of this study is to examine whether the association between compensation committee quality and the voluntary adoption of clawback provisions is affected by the amount of Level 3 fair values. We are interested in the moderating effect of the amount of fair values, because the relation between Level 3 fair values and the clawback provisions is unclear in the literature.

This paper contributes to a better understanding of how compensation committee structure can influence policies to punish management for financial misreporting. The results should help companies make decisions about whether to consider voluntary clawback adoption. Moreover, this study provides practitioners with insights that compensation committees are vital to voluntary clawback adoption. The findings add to the understanding that compensation committees make a valuable addition to the clawback provisions. Finally, this study contributes to the literature by examining the association between fair value reporting and voluntary clawback adoption.

Using a sample drawn from the U.S. firms from 2008 to 2015, the results show that the compensation committee quality is positively related to firm's voluntary adoption of clawback provisions. Additionally, the positive relationship between compensation committee quality and the voluntary adoption of clawback provisions is more pronounced for firms with higher Level 3 fair values.

The remainder of the study is organized as follows: section 1 introduces the literature review and hypotheses development, section 2 describes the sample selection techniques and the variables used in the empirical model, section 3 describes the empirical results, final section concludes the paper.

\section{BACKGROUND, LITERATURE AND HYPOTHESES}

\subsection{Literature and background for clawback provisions}

Under Sarbanes-Oxley Act Section 304 in 2002, the CEO and CFO must return incentive-based pay in the year prior to filing a restatement of earnings that is a result of accounting misconduct.
A clawback provision must specify what situations would trigger recoupment, how far the firm will reach back in time to recoup executive incentives, which components of compensation are subject to recapture, how deep within the firm to apply the policy, and whether to create a bonus bank that allows the firm to hold bonuses in escrow accounts for a period of time (Iskandar-Datta \& Jia, 2013). Thus, clawbacks are a mechanism designed to deter ex ante CEOs from publishing misstated accounting information and to penalize ex post CEOs (Dehaan et al., 2013). 
On July 1, 2015, the Securities and Exchange Commission (hereafter SEC) proposed new Rule 10D1 and related rule that would require clawbacks of CEO compensation in the event of subsequent accounting restatements ${ }^{1}$. Under the proposed new Rule 10D-1, listed companies would be required to disclosure of listed companies' recovery policies, and their actions under those policies. Although mandated clawback adoption is forthcoming, many firms adopted the clawback provisions voluntarily (Dehaan, 2013). Thus, this paper follows the prior literature by providing evidence from the viewpoint of voluntary adoption. In addition, corporate clawback provisions have recently been adopted in executive compensation contracts. In 2013, nearly $90 \%$ of the Fortune 100 in 2013 disclosed clawback policies (Equilar, 2013).

The prior literature provides evidence about the consequences of clawback provisions and indicates that managers, analysts (Dehaan et al., 2013), investors (Iskandar-Datta \& Jia, 2013), and auditors (Chan et al., 2012) may react to the adoption of clawbacks. For example, Dehaan et al. (2013) find that voluntarily adopting clawback provisions improves financial reporting quality. Iskandar-Datta and Jia (2013) indicate that clawback adoption has impacts on stock prices. They find that shareholders of firms with clawbacks experience positive stock valuation consequences. Chan et al. (2012) find that the adoption of clawback provisions increased accounting quality and lowered audit risk. Chan et al. (2015) document that clawback initiation leads firms to replace accounting-based earnings manipulation with real activity management.

Recent research also examines the economic determinants of firms' voluntary adoptions (Addy et al., 2014; Brown et al., 2015; Huang et al., 2015). Addy et al. (2014) find firms with entrenchment management makes a clawback provision less likely. In addition, they find that the interlocks of compensation committee with other companies with clawbacks increase the probability of adopting clawback provisions. Brown et al. (2015) find that firms that acquire targets with relatively poor accounting quality and with more negative $M \& A$ announcement returns are more likely to adopt clawbacks. In addition, they find that firms that adopt clawback provisions improve investor perception of M\&A quality, and CEOs are more responsive to the market. Huang et al. (2015) indicate that more co-opted boards are less likely to have clawbacks.

\subsection{Hypotheses development}

All corporate activity is the responsibility of the board of directors; however, compensation-related matters are assigned to compensation committees (Conyon \& Peck, 1998; Collins et al., 2009). Thus, the use of clawbacks would most likely be delegated to the compensation committee (Huang et al., 2015). An optimal contract is designed to maximize the net expected economic value to shareholders after transaction costs and payments to employees (Core et al., 2003). Under this viewpoint, compensation committees set executive incentive to minimize agency costs resulting from information asymmetry between shareholders and managers. Since boards have fiduciary duties to shareholders, the compensation committee may adopt a clawback provision. Adopting clawback provisions reflects independence and vigilance, illustrating that board interests coincide with the interests of outsiders.

The optimal contracting view posits that the board, working in the interests of the shareholders, provides the optimal incentives to align the interests of managers with those of the shareholders. However, Bebchuk and Fried (2003) suggest that directors' behaviors are also subject to an agency problem, which may undermine the effectiveness of incentive design. As such, a number of studies examine the effect of governance quality on different aspects of compensation design and provide evidence that it is at least partially supportive of this effect (e.g., Core et al., 1999; Newman \& Mozes, 1999; Perry \& Zenner, 2001; Vafeas, 2003). Motivated by the prior literature (Sun \& Cahan, 2009; Sun et al., 2009), this study takes the role of compensation committee quality into consideration. Sun et al. (2009) indicate that high-quality compensation committees can design CEO compensation that will lead managers with stronger incentives for future performance and reduce the ability of CEOs to extract rents. Vafeas (2003) in-

1 Data source https://www.sec.gov/rules/proposed/2015/33-9861.pdf 
dicates that directors with more reputation are less likely to collude with management when designing CEO compensation. Therefore, the reputation capital of the compensation committee provides strong incentives for the members to effectively monitor managers. Accordingly, this paper expects that firms with higher compensation committee quality are more likely to adopt a clawback provision. Therefore, the first hypothesis is formulated in alternate form:

H1: Ceteris paribus, there exists a positive relationship between the compensation committee quality and the voluntary adoption of clawback provisions.

Lev and Zhou (2009) indicate that fair values from SFAS No. 157 accurately conveyed the liquidity risk information to investors. They find three level separation potentially informs on liquidity risk; from the lowest risk - Level 1 - through the highest risk - Level 3. Liao et al. (2011) find that information asymmetry is significantly and positively associated with Levels 1,2 , and 3 fair values, which are specified in SFAS No. 157. Song et al. (2010) find that the value relevance of Level 3 is less than the value relevance of Level 1 and Level 2 fair values. Riedl and Serafeim (2011) indicate that firms with greater Level 3 fair values exhibit higher betas relative to those firms exposed to assets designated as Level 1 or Level 2. Altamuro and Zhang (2013) indicate that firms with more Level 3 fair values reflect the firms' risk characteristics.

Those literatures provide evidence that Level 3 inputs are the most problematic among the three tiers of fair value inputs. Because the measurement of Level 3 fair values is based on models with unobservable market inputs, the resulting fair values are difficult for outsiders to verify (Ryan, 2008). When fair value inputs become less observable, the degree of managerial discretion and uncertainty for fair value estimates is higher, and, in turn, the unreliability becomes more severe. Therefore, this paper expects that the positive relationship between compensation committee quality and the voluntary adoption of clawback provisions is positively affected by the degree of Level 3 fair values. Therefore, the second hypothesis is presented:
H2: The positive relationship between compensation committee quality and the voluntary adoption of clawback provisions is more pronounced for firms with higher Level 3 fair values.

\section{RESEARCH DESIGN}

\subsection{Regression models and variable definitions}

\subsubsection{Test of Hypothesis 1}

Hypothesis 1 states that there exists a positive relationship between the compensation committee quality and the voluntary adoption of clawback provisions. The dependent variable in this paper is a binary variable equal to one for firms that have adopted clawback provisions in year $t$ and zero otherwise. Thus, the probability of the existence of a clawback is examined using a logit regression. In order to establish the regression model, we modify the equation from Brown et al. (2015) to form the base model as follows:

$$
\begin{aligned}
& \text { CLAWBACK }{ }_{i t}=\alpha_{0}+\alpha_{1} C C Q+ \\
& +\alpha_{2} L E V F V A 3+\alpha_{3} F S I Z E+ \\
& +\alpha_{4} \text { PROFIT }+\alpha_{5} M B+\alpha_{6} R I S K+ \\
& +\alpha_{7} L E V+\alpha_{8} R E S T+ \\
& +\alpha_{9} \text { REST_IRR }+\alpha_{10} D U A L I T Y+ \\
& +\alpha_{11} \text { TENURE }+\alpha_{12} \text { BOUNS }+ \\
& +\alpha_{13} \text { SEG }+\alpha_{14} Y E A R \_D U M+ \\
& +\alpha_{15} I N D U_{-} \text {DUM }+\varepsilon_{i t} .
\end{aligned}
$$

The variable of interest in Hypothesis 1 is CCQ, which represents the degree of compensation committee quality. If the coefficient is positive, then, Hypothesis 1 is supported.

\subsubsection{Test of Hypothesis 2}

Hypothesis 2 states that the positive relationship between compensation committee quality and the voluntary adoption of clawback provisions is more pronounced for firms with higher fair value assets. In order to test Hypothesis 2, we modify equation (1) to form the second model as follows: 
$C L A W B A C K_{i t}=\beta_{0}+\beta_{1} C C Q+\beta_{2} L E V F V A 3+$ $+\beta_{3} C C Q \times L E V F V A 3+\beta_{4} F S I Z E+\beta_{5} P R O F I T+$ $+\beta_{6} M B+\beta_{7} R I S K+\beta_{8} L E V+\beta_{9} R E S T+$ $+\beta_{10} R E S T{ }_{-} I R R+\beta_{11} D U A L I T Y+\beta_{12} T E N U R E+$

$\beta_{13} B O U N S+\beta_{14} S E G+\beta_{m} \sum Y E A R \_D U M+$ $+\beta_{n} \sum I N D U_{-} D U M+\varepsilon_{i t}$.

The variable of interest in Hypothesis 2 is the interaction term $C C Q \cdot L E V F V A 3$, which captures the differential impact for firms with more fair value assets. If the coefficient is positive, then, Hypothesis 2 is supported.

\subsection{Variable definitions}

\subsubsection{Dependent variable}

According to Brown et al. (2015), the probability of the existence of a clawback (CLAWBACK) is a dummy variable that equal to one if firm has voluntarily adopted a clawback policy in year $t$ and zero otherwise; $t$ denotes the year of adoption.

\subsubsection{Independent variable - compensation committee quality (CCQ)}

This paper follows the prior literature (Sun et al., 2009; Dechow et al., 2010; Manchiraju et al., 2016) in that it considers seven proxies for compensation committee quality: the number of directors on the committee (CMSIZE), the aggregate directors' shareholdings (SHARES), whether a financial expert sits on the compensation committee (FINEXPERT), the proportion of directors on the committee with 10 or more years of board service (SENIOR), the proportion of CEO appointed directors on the compensation committee (APPOINT), the proportion of directors with three or more additional board seats on the compensation committee (BUSYDIR), and the proportion of CEOs from other firms on the committee (CEODIR). These proxies measure the independence, expertise, experience, and effectiveness of the compensation committee. The seven measures are converted to percentile scores from which an index, $C C Q$, is then constructed to capture the combined effect of these factors. CCQ equals the average of these seven percentile values.

\subsubsection{Independent variable - Level 3 fair values (LEVFVA3)}

LEVFAV3 is the fair value of Level 3 fair assets divided by total assets in fiscal year $t-1$.

\subsubsection{Control variables}

Following prior research (Addy et al., 2014; Brown et al., 2015), this paper also considers additional control variables. Firm size (FIZE) is measured as the logarithm of total assets of firm $i$ in year $t-1$. Profit (PROFIT) is measured as net income divided by the market value of equity in year $t-1$. Market-to-book ratio $(M B)$ is measured as (shares outstanding in year $t-1$ times end of year share price at year $t-1) /($ total assets at year $t-1-$ total liabilities at year $t-1)$. Firm risk (RISK) is measured as the standard deviation of daily stock returns for year $t-1$. Leverage $(L E V)$ is the ratio of total liabilities to total assets at the end of year $t-1$. Restatement (REST) is a dummy variable equal to 1 if the company had a restatement due to irregularities in the last five years (Hennes et al., 2008). Restate - irregularity (REST_IRR) is a dummy variable equal to one if firm had a restatement in years $t-5$ through $t-1$ that is classified as unintentional and zero otherwise. CEO-chair (DUALITY) is a dummy variable that equal to one if the $\mathrm{CEO}$ is the chair of the board at the end of year $t-1$, and zero otherwise. CEO tenure (TENURE) is the number of years the CEO has served of the end of year $t-1$. Bonus-tocash compensation (BONUS) is the amount of bonus paid to the CEO at the end of year $t-1$, divided by the cash compensation of the CEO at the end of year $t-1$. Complexity (SEG) is the number of segments in year $t-1$. Finally, the year-dummies (YEAR_DUM) and industry-dummites (INDU_DUM) are included to control for year-specific and industry-specific effects.

\subsection{Sample selection and data sources}

Firms are required to provide the Level 3 fair value hierarchy disclosure for the fiscal years beginning after November 15, 2007. We thus initially identify nonfinancial firms that adopted clawback provisions during the period 2008-2015 from the MSCI ESG research database. We limit our sample to nonfinancial firms because the majority of firms in the financial sector are subject to the mandatory adoption of clawback provision during the financial cri- 
sis in 2008 and 2009. We also require data availability on executive characteristics, financial variables, compensation committee characteristics and stock returns. These screening procedures make our final sample consisting of 4,098 firm-years for the sample period going from 2008 to 2015 .

We obtain executive characteristics from the ExecuComp database; financial information from the Compustat database; compensation committee characteristics from the RiskMetrics database; annual reports from the Edgar Online database and stock returns from the CRSP database.

\section{EMPIRICAL RESULTS}

\subsection{Descriptive statistics}

Table 1, which summarizes the descriptive statistics of the sample, shows that $62.2 \%$ of firms adopt clawback provisions. Table 1 also provides the de- scriptive statistics for director characteristics. On average, there are approximately 3.753 directors on a compensation committee (CMSIZE), and the aggregate shareholding of a compensation committee (SHARES) is $0.2 \%$. Of the firms, $47 \%$ have financial experts serving on their compensation committees (FINEXPERT). $39.1 \%$ of the directors have at least 10 years of board service time (SENIOR). $48.4 \%$ of the directors were appointed during the tenure of the incumbent CEO (APPOINT). While $9.5 \%$ of the observations have busy directors (BUSYDIR), 2.7\% of the directors are CEOs of other firms (CEODIR). The mean of Level 3 fair values (LEVFVA3) is $0.2 \%$ of the total assets.

With regard to the control variables, the average profit (PROFIT) is 0.037 , the average growth opportunities $(\mathrm{MB})$ is 3.272 , and the means and medians of firm size (SIZE), firm risk (RISK), firm leverage $(L E V)$ and are not skewed. $9 \%$ of firms had a restatement, while $0.1 \%$ firms had an intentional

Table 1. Descriptive statistics

\begin{tabular}{|c|c|c|c|c|c|c|c|c|}
\hline Variables & $\mathbf{N}$ & Means & Median & Std. Dev. & Minimum & Q1 & Q3 & Maximum \\
\hline$C L A W B A C K$ & 4,098 & 0.622 & 1.000 & 0.485 & 0.000 & 0.000 & 1.000 & 1.000 \\
\hline$C C Q$ & 4,098 & 0.633 & 0.634 & 0.137 & 0.200 & 0.539 & 0.736 & 0.978 \\
\hline CMSIZE & 4,098 & 3.753 & 4.000 & 1.040 & 1.000 & 3.000 & 4.000 & 8.000 \\
\hline SHART & 4,098 & 0.002 & 0.000 & 0.009 & 0.000 & 0.000 & 0.001 & 0.197 \\
\hline FIN EXPERT & 4,098 & 0.470 & 0.000 & 0.499 & 0.000 & 0.000 & 1.000 & 1.000 \\
\hline SENIOR & 4,098 & 0.391 & 0.333 & 0.291 & 0.000 & 0.200 & 0.667 & 1.000 \\
\hline$C E O A P P$ & 4,098 & 0.484 & 0.500 & 0.385 & 0.000 & 0.000 & 1.000 & 1.000 \\
\hline$B U S Y D I R$ & 4,098 & 0.095 & 0.000 & 0.163 & 0.000 & 0.000 & 0.200 & 1.000 \\
\hline CEODIR & 4,098 & 0.027 & 0.000 & 0.097 & 0.000 & 0.000 & 0.000 & 1.000 \\
\hline LEVFVA3 & 4,098 & 0.002 & 0.000 & 0.008 & 0.000 & 0.000 & 0.000 & 0.087 \\
\hline$F S I Z E$ & 4,098 & 8.056 & 7.928 & 1.545 & 3.997 & 6.902 & 9.076 & 13.590 \\
\hline PROFIT & 4,098 & 0.037 & 0.049 & 0.077 & -0.669 & 0.029 & 0.068 & 0.198 \\
\hline$M B$ & 4,098 & 3.272 & 2.394 & 2.894 & 0.248 & 1.615 & 3.816 & 26.718 \\
\hline RISK & 4,098 & 0.102 & 0.094 & 0.046 & 0.001 & 0.070 & 0.123 & 0.474 \\
\hline$L E V$ & 4,098 & 0.505 & 0.511 & 0.184 & 0.086 & 0.380 & 0.627 & 0.982 \\
\hline$R E S T$ & 4,098 & 0.090 & 0.000 & 0.286 & 0.000 & 0.000 & 0.000 & 1.000 \\
\hline$R E S T$ IRR & 4,098 & 0.001 & 0.000 & 0.035 & 0.000 & 0.000 & 0.000 & 1.000 \\
\hline DUALITY & 4,098 & 0.263 & 0.000 & 0.440 & 0.000 & 0.000 & 1.000 & 1.000 \\
\hline TENURE & 4,098 & 8.828 & 7.000 & 7.433 & 1.000 & 4.000 & 12.000 & 62.000 \\
\hline BONUS & 4,098 & 0.076 & 0.000 & 0.193 & 0.000 & 0.000 & 0.000 & 1.000 \\
\hline SEG & 4,098 & 7.927 & 7.000 & 4.612 & 1.000 & 5.000 & 10.000 & 40.000 \\
\hline
\end{tabular}

Note: $1 . N=4,098$. 2. Variable definitions: CLAWBACK is an indicator variable that is equal to one if firm $i$ has voluntarily adopted a clawback policy in year $t$ and zero otherwise; CCQ is firm's average score of compensation committee quality; CMSIZE is the number of directors on the committee; SHARE is the aggregate directors' shareholding; FIN_EXPERT is an indicator variable that equals one when there is a financial expert on the compensation committee, zero otherwise; SENIOR is the proportion of directors on the committee with 10 or more years of board service time; CEOAPP is the proportion of CEO appointed directors on the compensation committee; BUSYDIR is the proportion of directors with three or more additional board seats on the compensation committee; CEODIR is the proportion of the CEOs of other firms on the committee; LEVFVA3 is the Level 3 fair value of assets divided by total assets for fiscal year $t-1$; FSIZE is the logarithm of total assets of firm $i$ in year $t-1 ;$ PROFIT is measured as net income divided by the market value of equity in year $t-1 ; M B$ is the market-to-book ratio for year $t-1$; RISK is the standard deviation of daily stock returns for year $t-1 ; L E V$ is the ratio of total liabilities to total assets at the end of year $t-1 ; R E S T$ is a dummy variable equal to 1 if the company had a restatement due to irregularities in the last five years; REST_IRR is an indicator variable equal to one if firm $i$ had a restatement in years $t-5$ through $t-1$ that is classified as intentional, and zero otherwise; DUALITY is an indicator variable that is equal to one if the CEO is the chair of the board at the end of year $t-1$, and zero otherwise; TENURE is the number of years the CEO has served of the end of year $t-1 ; B O N U S$ is the amount of bonus paid to the CEO at the end of year $t-1$, divided by the cash compensation of the CEO at the end of year $t-1 ; S E G$ is the number of segments in year $t-1$. 
Table 2. Correlation analysis

\begin{tabular}{|c|c|c|c|c|c|c|c|c|c|c|c|c|c|c|}
\hline Variables & CLAWBACK & $C C Q$ & LEVFVA3 & FSIZE & PROFIT & $M B$ & RISK & LEV & REST & REST_IRR & DUALITY & TENURE & BONUS & $S E G$ \\
\hline CLAWBACK & 1.000 & - & - & - & - & - & - & - & - & - & - & - & - & - \\
\hline CCQ & -0.016 & 1.000 & - & - & - & - & - & - & - & - & - & - & - & - \\
\hline LEVFVA3 & $-0.061^{* * *}$ & -0.008 & 1.000 & - & - & - & - & - & - & - & - & - & - & - \\
\hline FSIZE & $0.281^{* * *}$ & $-0.252^{* * *}$ & $-0.064^{* * *}$ & 1.000 & - & - & - & - & - & - & - & - & - & - \\
\hline PROFIT & $0.050^{* * *}$ & $-0.020^{* *}$ & $-0.027^{*}$ & $0.122^{* * *}$ & 1.000 & - & - & - & - & - & - & - & - & - \\
\hline$M B$ & $0.090^{* * *}$ & $-0.040^{* * *}$ & $-0.045^{* * *}$ & $0.080^{* * *}$ & $0.037^{* *}$ & 1.000 & - & - & - & - & - & - & - & - \\
\hline RISK & $-0.187^{* * *}$ & 0.012 & $0.091^{* * *}$ & $-0.313^{* * *}$ & $-0.149^{* * *}$ & $-0.183^{* * *}$ & 1.000 & - & - & - & - & - & - & - \\
\hline LEV & $0.246^{* * *}$ & $-0.111^{* * *}$ & $-0.123^{* * *}$ & $0.472^{* * *}$ & -0.003 & $0.307^{* * *}$ & $-0.064^{* * *}$ & 1.000 & - & - & - & - & - & - \\
\hline RESTATEMENT & $-0.020^{* * *}$ & -0.004 & 0.003 & $-0.029^{*}$ & -0.008 & $-0.056^{* * *}$ & 0.007 & -0.022 & 1.000 & - & - & - & - & - \\
\hline RES_FRAUD & -0.002 & 0.020 & -0.009 & 0.007 & 0.004 & -0.014 & -0.019 & 0.023 & 0.014 & 1.000 & - & - & - & - \\
\hline DUALITY & $-0.102^{* * *}$ & $-0.192^{* * *}$ & $0.057^{* * *}$ & $0.064^{* * *}$ & 0.019 & $-0.059^{* * *}$ & $0.237^{* * *}$ & $0.061^{* * *}$ & $-0.030^{*}$ & -0.021 & 1.000 & - & - & - \\
\hline CEO_TENURE & $-0.139^{* * *}$ & $-0.040^{* *}$ & $0.062^{* * *}$ & $-0.143^{* * *}$ & -0.014 & 0.020 & $0.044^{* * *}$ & $-0.135^{* * *}$ & 0.014 & -0.010 & $0.112^{* * *}$ & 1.000 & - & - \\
\hline BONUS_RATIO & $-0.103^{* * *}$ & $0.031^{* *}$ & $0.033^{* *}$ & $0.053^{* * *}$ & 0.012 & $-0.032^{* *}$ & $0.059^{* * *}$ & $-0.039^{* *}$ & $0.016^{* *}$ & -0.014 & $0.038^{* *}$ & $0.046^{* * *}$ & 1.000 & - \\
\hline SEGNUM & $0.099^{* * *}$ & $-0.106^{* * *}$ & -0.016 & $0.249^{* * *}$ & 0.018 & $-0.080^{* * *}$ & $-0.061^{* * *}$ & $0.043^{* * *}$ & -0.014 & 0.023 & $0.030^{*}$ & $-0.073^{* * *}$ & -0.023 & 1.000 \\
\hline
\end{tabular}

Note: 1 . Pearson correlations are reported in the lower diagonal. 2. $N=4,098.3$. See Table 1 for variable definitions. $4 .{ }^{* * *}$, **, and ${ }^{*}$ indicate significance at the $1 \%, 5 \%$, and $10 \%$ levels, respectively. 
restatement. $26.3 \%$ of observations have the CEO serving as the chairman of the board (DUALITY). The average tenure of the CEO (TENURE) is 8.828 years. The average bonus ratio (BONUS) is $7.6 \%$. The average numbers of segments are 7.927.

\subsection{Correlation analysis}

Table 2 provides the results of the correlations among variables, with some coefficients warranting particular attention. Overall, the correlations are relatively small, and the low inter-correlations among all independent variables indicate that multi-collinearity does not appear to be a problem in the regression model.

\subsection{Regression analysis}

Table 3 reports the results for the hypothesis one and hypothesis two. Hypothesis one states that there exists a positive relationship between the compensation committee quality and the voluntary adoption of clawback provisions. The results show that the coefficient of compensation committee quality (CCQ) is significantly positive. Therefore, Hypothesis 1 is supported. This result is similar to the findings of prior literature, which showed that firms with strong governance are positively associated with the firm's adoption of a clawback provisions (Chen \& Vann, 2017). Compared with their research, this paper focuses on the role of compensation committee. The result shows that high-quality compensation committees can design CEO compensation that will reduce the ability of CEOs to extract rents.

Table 3 also reports the results for the hypothesis two. Hypothesis two states that the positive relationship between compensation committee quality and the voluntary adoption of clawback provisions is positively affected by the degree of Level 3 fair values. The interaction term CCQ LEVFVA3 is significantly positive, indicating that the positive relationship between compensation committee quality and the voluntary adoption of clawback provisions is more pronounced for firm with higher Level 3 fair values due to the information risk, inherent estimation errors, and possible reporting. The results support that the due to the information risk, inherent estimation errors, and possible reporting bias. Thus, Hypothesis 2 is supported.
Table 3. Model of clawback adoption

\begin{tabular}{|c|c|c|c|}
\hline Variables & Exp. sign & (1) & $(2)$ \\
\hline \multirow{2}{*}{ Intercept } & \multirow{2}{*}{$?$} & $-3.166^{* * *}$ & $-3.080^{* * *}$ \\
\hline & & $(-7.386)$ & $(-7.147)$ \\
\hline \multirow{2}{*}{$C C Q$} & \multirow{2}{*}{+} & $0.616^{* *}$ & $0.475^{*}$ \\
\hline & & $(2.102)$ & $(1.570)$ \\
\hline \multirow{2}{*}{ LEVFVA3 } & \multirow{2}{*}{$?$} & $9.201^{*}$ & -28.689 \\
\hline & & $(1.925)$ & $(-1.352)$ \\
\hline \multirow{2}{*}{$C C Q \cdot L E V F V A 3$} & \multirow{2}{*}{+} & - & $60.595^{* *}$ \\
\hline & & - & $(1.852)$ \\
\hline \multirow{2}{*}{ FSIZE } & \multirow{2}{*}{+} & $0.371^{* * *}$ & $0.372^{* * *}$ \\
\hline & & $(10.338)$ & $(10.364)$ \\
\hline \multirow{2}{*}{ PROFIT } & \multirow{2}{*}{+} & 0.546 & 0.527 \\
\hline & & $(1.131)$ & $(1.090)$ \\
\hline \multirow{2}{*}{$M B$} & \multirow{2}{*}{+} & -0.020 & -0.020 \\
\hline & & $(-1.301)$ & $(-1.303)$ \\
\hline \multirow{2}{*}{ RISK } & \multirow{2}{*}{$?$} & -0.896 & -0.902 \\
\hline & & $(-0.895)$ & $(-0.901)$ \\
\hline \multirow{2}{*}{ LEV } & \multirow{2}{*}{$?$} & $2.413^{* * *}$ & $2.408^{* * *}$ \\
\hline & & $(8.852)$ & $(8.828)$ \\
\hline \multirow{2}{*}{ REST } & \multirow{2}{*}{+} & -0.113 & -0.109 \\
\hline & & $(-0.893)$ & $(-0.867)$ \\
\hline \multirow{2}{*}{ REST_IRR } & \multirow{2}{*}{+} & -0.914 & -0.902 \\
\hline & & $(-0.923)$ & $(-0.911)$ \\
\hline \multirow{2}{*}{ DUALITY } & \multirow{2}{*}{-} & 0.120 & 0.122 \\
\hline & & $(1.093)$ & $(1.110)$ \\
\hline \multirow{2}{*}{ TENURE } & \multirow{2}{*}{-} & $-0.031^{* * *}$ & $-0.031^{* * *}$ \\
\hline & & $(-6.103)$ & $(-6.143)$ \\
\hline \multirow{2}{*}{ BONUS } & \multirow{2}{*}{ ? } & $-0.884^{* * *}$ & $-0.886^{* * *}$ \\
\hline & & $(-4.468)$ & $(-4.479)$ \\
\hline \multirow{2}{*}{ SEG } & & -0.004 & -0.005 \\
\hline & + & $(-0.463)$ & $(-0.481)$ \\
\hline YEAR DUMMIES & - & INCLUDE & INCLUDE \\
\hline $\begin{array}{l}\text { INDUSTRY } \\
\text { DUMMIES }\end{array}$ & - & INCLUDE & INCLUDE \\
\hline Pseudo $R^{2}$ & - & 0.178 & 0.179 \\
\hline Wald Chi ${ }^{2}$ & - & 699.018 & 700.446 \\
\hline Prob $>\mathrm{Chi}^{2}$ & - & $<.0001$ & $<.0001$ \\
\hline$N$ & - & 4,098 & 4,098 \\
\hline
\end{tabular}

Note: 1. See Table 1 for variable definitions. 2. This paper uses one-taired test if the hypothesis is directional. $3 .{ }^{* * *}$, ${ }^{* *}$, and ${ }^{*}$ indicate significance at the $1 \%, 5 \%$, and $10 \%$ levels, respectively. 4. Z-statistics are presented in parentheses. 5. All continuous variables are winsorized at 1 st and 99th percentiles to mitigate the influence of outliers. 


\section{CONCLUSION}

This paper examines how compensation committee quality affects the adoption of clawback provision. Additionally, this paper investigates whether the relationship varies with the Level 3 fair values. Using a sample drawn from the U.S. firms from 2008 to 2015, the results of the regression test show that there exists a positive relationship between the compensation committee quality and the voluntary adoption of clawback provisions. Additionally, the positive relationship between compensation committee quality and the voluntary adoption of clawback provisions is more pronounced for firms with higher Level 3 fair values. This paper contributes to a better understanding of how compensation committee structure can influence policies to punish management for financial misreporting. Moreover, this study provides practitioners with insights that compensation committees are vital to the voluntary clawback adoption. Finally, this study contributes to the literature by examining the association between fair value reporting and voluntary clawback adoption.

\section{ACKNOWLEDGEMENT}

The authors acknowledge the financial support of Ministry of Science and Technology, R.O.C. (project number MOST 105-2410-H-035-019-).

\section{REFERENCES}

1. Addy, N., Chu, X., \& Yoder, T. (2014). Voluntary adoption of clawback provisions, corporate governance, and interlock effects. Journal of Accounting and Public Policy, 33(2), 167-189. https:// doi.org/10.1016/j.jaccpubpol.2013.12.001

2. Adut, D., Cready, W., \& Lopez, T. (2003). Restructuring charges and CEO compensation: a reexamination. The Accounting Review, 78(1), 169-192. Retrieved from http:// www.jstor.org/stable/3203300

3. Altamuro, J., \& Zhang, H. (2013). The financial reporting of fair value based on managerial inputs versus market inputs: evidence from mortgage servicing rights. Review of Accounting Studies, 18(3), 833-858. Retrieved from https://link.springer.com/ article/10.1007\%2Fs11142-0139234-y

4. Barclay, M., Gode, D., \& Kothari, S. (2005). Matching delivered performance. Journal of Contemporary Accounting \& Economics, 1(1), 1-25. Retrieved from https://www. sciencedirect.com/science/article/ pii/S1815566910700011

5. Barth, M. E., \& Landsman, W. R. (1995). Fundamental issues related to using fair value accounting for financial reporting. Accounting Horizons, 9(4), 97-107. Retrieved from http://connection.ebscohost. com/c/editorials/9512111884/ fundamental-issues-related-usingfair-value-accounting-financialreporting

6. Barth, M. E., Landsman, W., \& Lang, M. (2008). International accounting standards and accounting quality. Journal of Accounting Research, 46(3), 467-498. https://doi.org/10.1111/j.1475679X.2008.00287.x

7. Bebchuk, L. A., \& Fried, J. M. (2003). Executive compensation as an agency Problem. Journal of Economic Perspectives, 17(3), 71-92. https://doi.org/10.3386/w9813

8. Brown, A., Davis-Friday, P. Y., Guler, L., \& Marquardt, C. (2015). M\&A decisions and U.S. firms' voluntary adoption of clawback provisions in executive compensation contracts. Journal of Business, Finance, and Accounting, 42(1-2), 237-271. https://doi.org/10.1111/ jbfa.12111

9. Chan, L. H., Chen, K. C. W., \& Chen, T. T. (2013). The effects of firm-initiated clawback provisions on bank loan contracting. Journal of Financial Economics, 110(3), 659-679. https://doi.org/10.1016/j. jfineco.2013.08.010

10. Chan, L. H., Chen, K. C. W., Chen, T. Y., \& Yu, Y. (2015). Substitution between real and accruals-based earnings management after voluntary adoption of compensation clawback provisions. The Accounting Review, 90(1), 147-174. https:// doi.org/10.2308/accr-50862

11. Chan, L. H., Chen, K. C. W., Chen, T. Y., \& Yu, Y. (2012). The effects of firm-initiated clawback provisions on earnings quality and auditor behavior. Journal of Accounting and Economics, 54(2-3), 180-196. https://doi.org/10.1016/j. jacceco.2012.05.001

12. Chen, Y., \& Vann, C. E. (2017). Clawback provision adoption, corporate governance, and investment decisions. Journal of Business Finance \& Accounting, 44(9-10), 1370-1397. https://doi. org/10.1111/jbfa.12259

13. Chen, F., Kevin, L., Smieliauskas, W., \& Ye, M. (2011). Fair value measurements and auditor versus management conservatism: evidence from the bank- 
ing industry (Working Paper). University of Toronto. Retrieved from https://www.researchgate. net/publication/256004406_Fair_ Value_Measurements_and_Auditor_versus_Management_Conservatism_Evidence_from_the Banking_Industry

14. Collins, D., Gong, G., \& Li, H. (2009). Corporate governance and backdating of executive stock options. Contemporary Accounting Research, 26(2), 403-445. https:// doi.org/10.1506/car.26.2.4

15. Conyon, M. J., \& Peck, S. I. (1998). Board control, remuneration committees, and top management compensation. Academy of Management Journal, 41, 146-157. Retrieved from https://www.jstor. org/stable/257099? seq=1\#page _ scan_tab_contents

16. Core, J., Gua, W., \& Larcker, D. (2003). Executive equity compensation and incentives: A Survey. Economic Policy Review, 9, 27-50. Retrieved from https://ideas.repec. org/a/fip/fednep/y2003iaprp2750nv.9no.1.html

17. Core, J., Gua, W., \& Holthausen, R. (1999). Corporate governance, chief executive officer compensation, and firm performance. Journal of Financial Economics, 51(3), 371-406. https://doi.org/10.1016/ S0304-405X(98)00058-0

18. Daske, Q., Hail, L., Leuz, C., \& Verdi, R. (2008). Mandatory IFRS reporting around the world: early evidence on the economic consequences. Journal of Accounting Research, 46(5), 1085-1142. https://doi.org/10.1111/j.1475679X.2008.00306.x

19. Dechow, P. M., Myers, L., \& Shakespeare, C. (2010). Fair value accounting and gains from asset securitizations: A convenient earnings management tool with compensation side-benefits. Journal of Accounting Economics, 49(12), 2-25. https://doi.org/10.1016/j. jacceco.2009.09.006

20. Dechow, P. M., Huson, M. R., \& Sloan, R. G. (1994). The effect of restructuring charges on executives' cash compensation. The Accounting Review, 69(1), 138-156. Retrieved from http://www.jstor. org/stable/248264
21. Dehaan, E., Hodge, F. D., \& Shevlin, T. J. (2013). Does voluntary adoption of a clawback provision improve financial reporting quality? Contemporary Accounting Research, 30(3), 1027-1062. https://doi.org/10.1111/j.19113846.2012.01183.x

22. Fiechter, P., \& Meyer, C. (2011). Discretion in Fair Value Measurement of Banks During the 2008 Financial Crisis (Working paper). University of Zurich. Retrieved from https://papers.ssrn.com/sol3/ papers.cfm?abstract_id=1522122

23. Gaver, J. J., \& Gaver, K. M. (1998). The relation between nonrecurring accounting transactions and CEO cash compensation. The Accounting Review, 73(2), 235-253. Retrieved from http://www.jstor. org/stable/248467

24. Goh, B. W., Ng, J., \& Yong, K. O. (2011). Fair value disclosures beyond SFAS 157 (Working paper). Singapore Management University. Retrieved from https:// www.researchgate.net/publication/228258552_Fair_Value Disclosures_Beyond_SFAS_157's_ Three-Level_Estimates

25. Hennes, K. M., Leone, A. J., \& Miller, B. P. (2008). The importance of distinguishing errors from irregularities in restatement research: The case of restatements and CEO/CFO turnover. The Accounting Review, 83(6), 1487-1519. Retrieved from http://www.jstor. org/stable/30243804

26. Huang, S., Lim, C. Y., \& Ng, J. (2015). Not clawing the hand that feeds you: The case of co-opted boards and clawbacks (Working Paper). Singapore Management University. Retrieved from https:// papers.ssrn.com/sol3/papers. cfm?abstract_id=2538916

27. Iskandar-Datta, M., \& Jia, Y. (2013). Valuation consequences of clawback provisions. The Accounting Review, 88(1), 171-198. https:// doi.org/10.2308/accr-50262

28. Kolev, K. (2009). Do investors perceive marking-to-model as marking-to-myth? early evidence from FAS 157 disclosure (Working Paper). NYU Stern School of Business. Retrieved from https:// papers.ssrn.com/sol3/papers. cfm?abstract $\_$id $=1336368$

29. Landsman, W. R. (2007). Is Fair Value accounting information relevant and reliable? evidence from capital market research. Accounting and Business Research Special Issue: International Accounting Policy Forum, 37, 19-30. https:// doi.org/10.1080/00014788.2007.9 730081

30. Laux, C., \& Leuz, C. (2009). The crisis of fair value accounting: making sense of the recent debate Accounting, Organizations and Society, 34(6-7), 826-834. https://doi. org/10.1016/j.aos.2009.04.003

31. Leone, A. J, Wu, J. S., \& Zimmerman, J. L. (2006). Asymmetric sensitivity of CEO Cash Compensation to Stock Returns. Journal Accounting Economics, 42(1-2), 167-192. https://doi.org/10.1016/j. jacceco.2006.04.001

32. Lev, B., \& Zhou, N. (2009). Unintended consequence: fair value accounting informs on liquidity risk (Working paper). New York University. Retrieved from https:// papers.ssrn.com/sol3/papers. cfm?abstract_id=1466009

33. Liao, L., Kang, H., Morris, R. D., \& Tang, Q. (2011). Information asymmetry of fair value accounting during the global financial crisis (Working paper). The University of New South Wales. Retrieved from http://researchdirect. westernsydney.edu.au/islandora/ object/uws:27950

34. Manchiraju, H., Hamlen, S., Kross, W., \& Suk, I. (2016). Fair value gains and losses in derivatives and CEO compensation. Journal of Accounting, Auditing \& Finance, 31(3), 311-338. https://doi.org /10.1177\%2F0148558X15584238

35. Newman, H. A., \& Mozes, H. A. (1999). Does the composition of the compensation committee influence CEO compensation practices? Financial Management, 28(3), 41-53. Retrieved from http://www.jstor.org/stable/3666182

36. Paananen, M., Renders, A., \& Shima, K. (2011). Management motivations for SFAS 157 reclas- 
sifications and the capital market consequences (Working paper). University of Hertfordshire.

37. Penman, S. H. (2007). Financial reporting quality: Is fair value a plus or minus? Accounting and Business Research (Special Issue: International Accounting Policy Forum), 37(1), 33-34. https://doi.org/ 10.1080/00014788.2007.9730083

38. Perry, T., \& Zenner, M. (2001). Pay for Performance? Government regulation and the structure of compensation contracts. Journal of Financial Economics, 62(3), 453-488. https://doi.org/10.1016/ S0304-405X(01)00083-6

39. Riedl, E., \& Serafeim, G. (2011). Information risk and fair values: An examination of equity betas. Journal of Accounting Research, 49(4), 1083-1122. https://doi.org/10.1111/j.1475 679X.2011.00408.x

40. Ryan, S. G. (2008). Accounting in and for the subprime crisis. The Accounting Review, 83(6), 16051638. https://doi.org/10.2308/ accr.2008.83.6.1605
41. Scott, M., \& Seelig, S. (2010). Mandated clawbacks will create new tensions between executives and boards. Retrieved from https://www.towerswatson.com/ en/Insights/Newsletters/Americas/ Insider/2010/Mandated-Clawbacks-Will-Create-New-TensionsBetween-Executives-and-Boards

42. Song, C., Thomas, W., \& Yi, H. (2010). Value relevance of FAS No. 157 fair value hierarchy information and the impact of corporate governance mechanisms. The Accounting Review, 85(4), 13751410. https://doi.org/10.2308/ accr.2010.85.4.1375

43. Sun, J., \& Cahan, S. (2009). The effect of compensation committee quality on the association between $\mathrm{CEO}$ cash compensation and accounting performance. Corporate Governance: An International Review, 17(2), 193-207. https://doi.org/10.1111/j.14678683.2008.00726.x

44. Sun, J., Cahan, S. F., \& Emanuel, D. (2009). Compensation com- mittee governance quality, Chief Executive Officer stock option grants and future firm performance. Journal of Banking and Finance, 33(8), 1507-1519. https://doi.org/10.1016/j.jbankfin.2009.02.015

45. Vafeas, N. (2003). Further evidence on compensation committee composition as a determinant of CEO compensation. Financial Management, 32, 53-70. Retrieved from https://www.jstor.org/ stable/3666336?seq=1\#page_scan_ tab_contents

46. Valencia, A. (2011). Opportunistic behavior using Level 3 fair-values under SFAS157 (Unpublished Doctoral dissertation). The Florida State University. Retrieved from http://fsu.digital.flvc.org/ islandora/object/fsu\%3A254344

47. Watts, R. (2003). Conservatism in accounting part II: Evidence and research opportunities. Accounting Horizon, 17(4), 287330. https://doi.org/10.2308/ acch.2003.17.4.287 